\title{
Spending eternity in liquid nitrogen
}

I $\mathrm{n}$ the mind of cryonicists, it would be entirely inappropriate to refer to a frozen corpse as a corpsicle. In their lingo, after all, a patient is not dead, but rather, "deanimated."

Welcome to the nuances of cryonics - the practice of preserving a legally dead person at a temperature far below freezing in hopes of someday being revived and rejuvenated after advances in science have provided a cure for their ailment.

The appeal is self-evident, enthusiasts say. "It certainly offers an opportunity, although remote and probably speculative, as an ambulance to the future so to speak," says Ilir Dema, a 47-year-old from Toronto, Ontario, who has made cryopreservation arrangements. "If I die from something that is not preventable today, maybe future technology will offer the means of reviving me, figuring out the condition I have and fixing it."

Yet, however appealing the notion of a second life may be, the number of people who've actually been frozen is minuscule: about 250, according to the Cryonics Institute, a cryonics services provider located in a regional township of the state of Michigan (http://cryonics.org/comparisons.html).

But far more people appear interested in being frozen. Membership in the two biggest cryonics providers in the United States - the Cryonics Institute and the Alcor Life Extension Foundation in Scottsdale, Arizona - is close to 2000.

Cryonicists (who are defined by the field as those who perform the procedure and those interested in having it done) are quick to dismiss the notion that the practice involves raising the dead.

They argue that the concept of death is actually a matter of debate, contending that when a person is pronounced dead by a clinician, he is still not in a state of absolute death, but merely at a point where there are a number of processes that can be halted indefinitely via freezing, preserving that person into

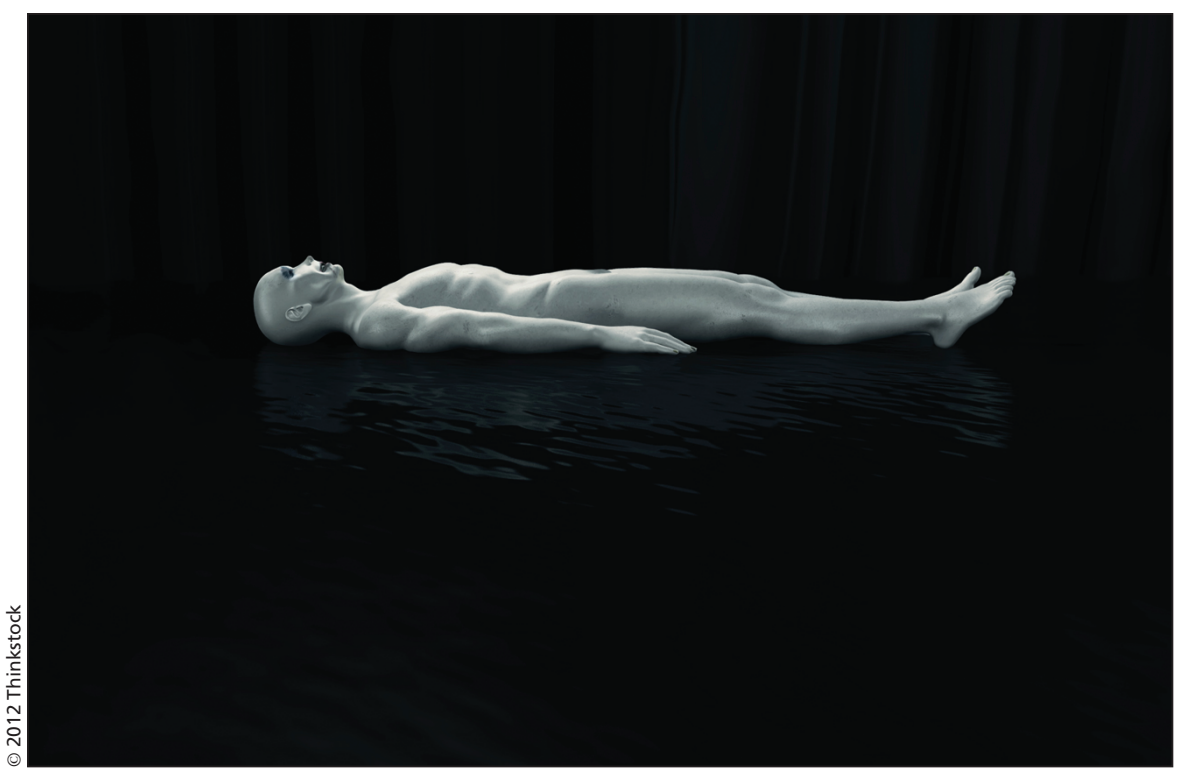

Cryonicists admit they're not certain about the degree of scientific progress that will have to be made in order to reanimate corpses, or just how far away into the future that might conceivably be.

the future, where his condition can be treated or reversed.

Because it is illegal to perform cryonics on a person who has yet to be pronounced dead by a qualified physician, cryonicists essentially bank on drawing a line between clinical and what they call "biological" death, and thus, feel entitled to refer to the dead as merely the "deanimated."

The cryonics process involves draining a patient's fluids and replacing them with a vitrification solution, essentially a preservative cocktail of cryoprotectant chemicals such as dimethylsulfoxide, ethylene glycol, propylene glycol and glycerol that are believed to prevent ice crystal formation and reduce the extent of tissue damage that occurs after flesh is frozen. The corpse is allowed to cool and then dropped into liquid nitrogen for indefinite preservation at a brisk $-196^{\circ} \mathrm{C}$.

Or as Ben Best, president of the Cryonics Institute, writes in an email "the perfusion process involves replacing body water in cells, not just blood in the blood stream. By perfusing vitrification solution into the blood stream, there is an exchange of vitrification solution for water. Water is removed from the body (and tissues) as vitrification solution replaces it by the diffusion process. With vitrification solution in brain tissue (especially) there should be no ice formation whatsoever. The flesh is therefore vitrified, not frozen (freezing means ice). The patient is cooled under a computer controlled cooling box to liquid nitrogen temperature, not simply 'dropped' in liquid nitrogen."

Cryonicists acknowledge that storing a body at such a low temperature and using such toxic chemicals cause considerable physical damage to the corpse. But they're hopeful that future scientific discoveries will allay those side effects, as well as the disease or ailment that led to death.

The goal is neurological preservation, cryonicists say, adding that if the structure of the brain can be maintained, future technologies may be able to restore the personality and memories contained therein. Hence the rationale for swift vitrification: minimizing damage to the brain.

As a process and an industry based 
entirely on a principle of hope, cryonicists and enthusiasts are careful to acknowledge that the speculative nature of the venture leaves little room for any manner of guarantee.

"Realistically, I don't think there is evidence of strong odds at this point in time in favour of it being successful," says Corey Turnbull, a 35-year-old member of the Cryonics Society of Canada. "I think anyone going into it has to be aware of that, but obviously optimistic about the future."

Cryonicists admit they're not certain about the degree of scientific progress that will have to be made in order to reanimate corpses, or just how far away into the future that might conceivably be. Some herald molecular nanotechnology as a prime candidate for reversing damage caused by cryopreservation and a possible tool in restoring corpses to life and health.

Others point to some manner of cyber-solution, such as "mind uploading," in which high-fidelity imaging technology would be used to produce an image of the brain that can be run as a simulacrum on more advanced forms of computer hardware.

That, skeptics say, is outright science fiction.

To which enthusiasts shrug.

"Most people do not think it's going to work and they might be right," says Charles Grodzicki, a 73-year-old in West Vancouver, British Columbia, who's making cryopreservation arrangements. "I personally give it a long shot, but it's a better shot than none at all."

Those interested in being preserved in liquid nitrogen have few options in terms of providers. Two - the Cryonics Institute and Alcor Life Extension Foundation - dominate the market, although there are a few smaller facilities scattered around the world.

But selection of a smaller facility entails its own risks, as the relatives of nine corpses discovered in California in 1979 when the firm that was to have been responsible for their preservation went belly up and the "cryonics patients" that were ostensibly to have been in liquid nitrogen were found in a state of decomposition.

There's also the problem of proxim- ity to a provider, although some firms have been created, such as one in Florida called Suspended Animation, Inc., to offer rapid transportation to preservation and storage facilities. Currently, the long-distance hauling service is only available in the US.

Then there's the matter of cost.

That is considerable, ranging from US\$28 000 to US $\$ 200000$, depending on the facility, nature of services selected and the immediacy of vitrification.

An enthusiast can request that a team wait nearby while he dies so that his corpse can be quickly whisked away to launch the cryopreservation process as shortly as possible after a qualified medical professional pronounces death.

Providers say they prefer that people pay for cryopreservation services by designating their firm as the beneficiary of a life insurance policy, although clearly sizable quantities of cash would also be acceptable.

"The great majority of cryonicists fund their cryonics arrangements by having a life insurance policy that names a cryonics organization as the beneficiary in the event of their death. There are other funding arrangements, but designating their estate to make the payments is not allowed because that would involve delays, and a probate process that could be contested," Best writes.

Cryopreservation, itself, appears to come in several flavours: whole body or "neuro." The latter, in turn, seems available in "head only" or "brain only" varieties.

It's all about "neuropreservation," according to Alcor's website. "Cryopreservation that is focused on doing the best possible job to preserve the human brain is called 'neuropreservation'. The brain is a fragile organ that cannot be removed from the skull without injury, so it is left within the skull during preservation and storage for good ethical and scientific reasons. This gives rise to the mistaken impression that Alcor preserves 'heads'. It is more accurate to say that Alcor preserves brains in the least injurious way possible. As a practical matter, cephalic isolation (or 'neuroseparation') is performed by surgical transection at the sixth cervical vertebrae.
Non-cryopreserved tissue is handled in accordance with member wishes. Cremation is common."

The choice, in turn, affects the price tag of services. Alcor is the sole provider offering the neuro option, for a mere US\$80 000, as compared with US\$200 000 typically sought for complete body treatment. More than half of Alcor's 110 cryonics patients are neuro cases (http://alcor.org/cases.html).

The neuro option invariably engenders bad publicity, Best says.

Or as the firm's website notes, "journalists and horror novelists invariably have a field day with 'frozen severed heads,' and focus not on the scientific or humanitarian sense of cryonics, but on making cryonics look grotesque or ridiculous" (http://cryonics .org/prod.html).

Neither Canada nor the US prohibits the practice of cryonics, though provincial legislation in $\mathrm{BC}$ restricts the marketing of cryonics. No person may sell or offer to sell "an arrangement for the preservation or storage of human remains ... on the expectation of the resuscitation of human remains at a future time" according to the province's "Cremation, Internment and Funeral Services Act" (www.bclaws.ca /EPLibraries/bclaws_new/document/ID /freeside/00_04035_01).

That's occasionally caused a problem, says 27-year-old Keegan Macintosh, a third-year law student at the University of British Columbia, a director of the Cryonics Society of Canada and head of the UBC Life Extension Club.

Although BC's law only restricts the sale and marketing of cryonics arrangements, it does not prohibit people from making arrangements with providers in the US and does not prohibit funeral directors in $\mathrm{BC}$ from assisting in the preparation and transport of patients to a storage facility, Macintosh says.

Cryonicists would nevertheless like to see it struck from the books, he adds. "It remains to be seen whether the mere existence of the law is having what you might call a chilling effect — pardon the pun - on funeral directors in British Columbia." - Michael Monette, Ottawa, Ont.

CMAJ 2012. DOI:10.1503/cmaj.109-4144 